\title{
Implementation of KPU Regulation No. 2 of 2017 by Minahasa KPUD on The Implementation of Pemilukada 2018
}

\author{
$1^{\text {st }}$ Fitri H. Mamonto \\ Public Administration Study \\ Program \\ Manado State University \\ Tondano, Indonesia \\ E-mail: yombog@yahoo.com \\ $4^{\text {th }}$ Itje Pangkey \\ Public Administration Study \\ Program \\ Faculty of Social Sciences \\ Universitas Negeri Manado \\ Manado, Indonesia \\ Itjepangkey@unima.ac.id
}

\author{
$2^{\text {nd }}$ Jeane E. Langkai \\ Public Administration Department \\ Faculty of Social Science \\ Universitas Negeri Manado \\ Manado, Indonesia \\ jeanelangkai@unima.ac.id \\ $5^{\text {th }}$ Jeane Mantiri \\ Public Administration Department \\ Universitas Negeri Manado \\ Tondano, Indonesia \\ jeanelitha@unima.ac.id
}

\author{
$3^{\text {rd }}$ Recky H. E. Sendouw \\ Public Administraton Department \\ Faculty of Social Science \\ Manado, Indonesia \\ reckysendouw@unima.ac.id
}

\begin{abstract}
The purpose of this study is 1). To find out how the implementation of KPU (General Elections Commission) regulation number 2 of 2017 by Minahasa KPUD (Regional General Elections Commission) on Pemilukada (Regional Heads Election) 2018. 2). To determine the factors that influence the implementation of KPU (General Elections Commission) regulation number 2 of 2017 by the Minahasa KPUD (Regional General Elections Commission) on Pemilukada (Regional Heads Election) 2018. To answer the purpose of this study, the researcher conducted a research based on qualitative descriptive methods with data analysis through three stages, namely reduction, presentation and verification of data, in this case carried out from the beginning to the end of this study. Based on research data and analysis, it could be concluded that the duties and responsibilities of Minahasa KPUD (Regional General Elections Commission) against policies related to KPU (General Elections Commission) regulation number 2 of 2017 in updating the data are crucial in the process of working this PKPU implementation. In addition, there are 5 factors that influence PKPU's implementation by the Minahasa KPUD (Regional General Elections Commission), namely: a). Communication Factors. b). Resource Factors. c). Characteristics of Implementing Agents, d) Relationships between organizations e). Implementation attitude.
\end{abstract}

Keywords: Implementation, Policy, Pemilukada (Regional Heads Election)

\section{INTRODUCTION}

The General Election becomes a means of democracy which is evidence of an order of life of the state and sovereign society and as a form of a government of the people by the people and for the people. Through the general election, at least there are three things that are targeted. First, through general election we can obtain our political rights in participating in determining the future of the nation at the same time and involving all the people of Indonesia. Second, through the general election there will be leaders and representatives of the people produced through fair, transparent and quality political mechanisms. Third, from a general election there can be a healthy and peaceful succession process. Historically, the General Elections in Indonesia were originally intended to elect citizens to become representatives of the people in the DPR, Provincial DPRD, and Regency/City DPRD. However, with the implementation of the fourth amendment of the 1945 Constitution in 2002, the Presidential Election and vice president, which was initially chosen by the MPR, has been amended by direct elections by the people as a form of democratic people's sovereignty by direct elections. Following this, Law Number 22 of 2007 was established which ensured that the election of regional heads and deputy 
regional heads (Pemilukada) was also included as part of the general election.

In supporting the creation of a democratic, quality and dignified election, based on Law Number 7 of 2017 Article 1 paragraph 7, election organizers are the institutions that hold elections which consist of the General Election Commission and Election Supervisory Agency as one the unity of the function of organizing the General Election to elect members of the Regional Representative Board, Regional House of Representatives, President and Vice President directly. Also affirmed in Article 1 paragraph 8 of Law Number 7 of 2017, the General Election Commission, hereinafter abbreviated as $\mathrm{KPU}$, is a national, permanent and independent Election Organizing Agency in charge of carrying out elections. National character illustrates that the scope of work and responsibilities of the KPU (General Elections Commission) as the organizer of the General Elections covers the entire territory of the Republic of Indonesia. The nature remains to show General Elections Commission as an institution that carries out continuous tasks despite being limited by a certain term of office. Independent nature confirms that the General Elections Commission in holding general elections is free from the influence of any party.

In 2018 is a political year for the Indonesian society, especially Regional Heads Election which is held in 171 Regions with details of 17 Provincial Elections to elect the Governor and its representatives, 39 Cities to elect the Mayor and their representatives and 115 Regencies to elect the Regent and his representatives[1]. In this case also the Minahasa Regency which will elect the regent and his deputy. Minahasa Regency as one of the regions that participated in organizing Regional Heads Election, also demanded quality and dignified implementation in accordance with Article 1 paragraph 8 of Law Number 7 of 2017, the Minahasa Regional General Election Commission (KPUD) as General Election organizing institutions in the District that responsible for carrying out General Election stage held on June 27, 2018. In carrying out these stages the Regional General Elections Commission (KPUD) is guided by a schedule of stages that have been set forth in the General Election Commission Regulation number 1-5 of 2017 concerning Simultaneous Regional Elections 2018.
One of the most crucial stages in the implementation of the General Election is the stage of updating and compiling the voter list based on PKPU Number 2 of 2017 concerning Data Updating and Preparation of the Voters List in all levels of the governor and his deputy, the regent and his deputy and the mayor and his deputy. Data updating and preparation of the voters list according to the schedule stages, starts on December 30, 2017, which is almost six months before the voting day, which is on June 27, 2018. An important requirement for democratic and quality elections is the high participation of citizens in exercising their right to vote so that it is deemed necessary to pay special attention to the assurance of the constitutional rights of every citizen in exercising their right to vote in the holding of 2018 Regional Heads Election.

The most important problem faced in the simultaneous regional elections in 2015 is that there are still many voters who have not been accommodated in the final voter list. According to [1]. The 2015 elections were attended by 101 regions spread across 7 (seven) provinces and 18 cities and 76 regencies in Indonesia, of which 41.1 million people had the right to vote, there were 691,611 people not accommodated in the final voter list.

Learning from the experience in the Regional Heads Election, the Minahasa KPUD has carried out PKPU Number 2 of 2017 with the result that in the 2018 Regional Heads Election the number of DPT is 251,140 voters, whereas previously based on DPS there were 252,983 voters or there were 1,843 voters who did not have rights or $0.73 \%$ of the number of DPS previously announced. In PKPU, it has opened as many opportunities as possible to the compulsory voters to be able to use their voting rights in the 2018 Regional Heads Election, including Minahasa citizens to elect their regents and representatives, including if the compulsory voters are not registered in the DPT, they can still be accommodated in the Special Voter List (DPK) or Additional Special Voter List.

From the description above, the researcher is interested in conducting research on the Implementation of KPU Regulation Number 2 of 2017 concerning Data Updating and Preparation of Voter List in the Election of regents and his representatives in regency. And based on the background of the above problems, the researcher has formulated the problem as follows: 1). How is the 
Implementation of KPU Regulation Number 2 of 2017 by the Minahasa KPUD in 2018? 2). What are the factors that influence the implementation of KPU Regulation Number 2 of 2017 by Minahasa KPUD in 2018 ?

According to [2], the main procedure of democracy is how the election of prospective leaders occurs through a competitive way determined by the citizens. The most important thing is that the election is a form of commitment (spirit) of democracy, where the substance is the formation of a government/leadership of the people by the people and for the people. That is, the people hold the highest power.

General elections are an important process to produce a government that has a high commitment to fresh ideas. The General Election will produce seats in the parliament after the people's votes are won by political parties and candidates. General elections are the best effort to choose representatives of the people who will truly work to represent the people in the country's policy-making process [3].

The conclusion is, General Election is a democratic process in Indonesia in which there are political practice procedures in order to strengthen people's sovereignty which can be the beginning of the formation of a government in the form of representative government. In simple language, General Elections can be formulated as an effort or means in choosing the people who will represent the people to run the government.

In the general election the main contestation is political parties in which the political parties represent the specific interests of citizens. These interests are among others: about religious values, about justice, people's welfare, a sense of nationalism, anti-corruption attitudes. Things like these become an issue in every campaign to appeal to the public. Therefore, the goodness of an electoral system if the system is able to accommodate different interests in each community levels, so that it is represented in the process of determining state policy in parliament.

In fact, there are four purposes for organizing elections, namely [4]:

1. To enable the succession process of government leadership to take place in an orderly and peaceful manner
2. To create the regeneration process or individuals who immediately take up government positions that will represent the interests of the people in representative institutions

3. To realize the principle of sovereignty

4. To safeguard the fundamental rights of citizens.

On the other hand, it cannot be denied, the polarization of political parties is also more or less influenced by the electoral system, there are two electoral systems, namely: district/majority representatives (single member constituency) and proportional representation systems. However, in organizing general elections the most important thing is that the countries have the right to become voters in general elections, especially in the 2018 Regional Heads Election. Law Number 7 of 2017 Article 1 paragraph 34 and KPU Regulation Number 2 of 2017 Article 1 paragraph 15 which states that Indonesian citizens who have the right to vote are those who are 17 (seventeen) years old or older or have been married.

Here it is clear that all Indonesian citizens who have fulfilled these conditions already have constitutional rights to vote in general elections, either the Legislative Election, Presidential General Election and Vice President or in the Regional Heads Election. To be able to exercise their right to vote, every citizen must be registered in the Voters List through a process of data updating carried out by the KPU ahead of the General Election including Pemilukada (Regional Heads Election).

On the other hand, the birth of PKPU Number 2 of 2017 is a product of public policy in the implementation of Pemilukada (Regional Heads Election) so that it can run democratically and high of quality. Klein and Murpy in [5] say policies are all express or implied instructions that establish organizational goals and objectives target of organization and suitable ways to be used in achieving that goal. Short words of policy according to Klein and Murpy [5] mean a set of rules that guide an organization; the policy covers the entire organization's instructions. According to Laswell and Kaplan in [6], public policy is a program that is projected with certain goals, certain values, and certain practices that actually must be implemented so that the objectives of the policy are likely to be achieved. 
In a public policy process, implementation of policy implementation is one of the stages that must be passed. Indeed, implementation is implemented after a policy is formulated based on clear objectives. Indeed, implementation can be interpreted as a series of activities or activities in an effort to bring the policy to the community so that the policy should have an impact as expected. The series of activities consists of various regulations that arise after the first existence of a set of rules that are the result of the interpretation of the previous regulations [7].

According to Mazmanian and Sabatier in [8] implementation is a real understanding of the enactment of a program which is the focus of attention on policy implementation, namely events that arise after the approval of state policy guidelines, both efforts to administer it and for real consequences for the community.

\section{RESEARCH METHODS}

In this study, researchers used a qualitative research method which is a research method based on natural conditions with interpretive and constructive paradigms by looking at the PKPU's implementation quality of virtue No. 2 of 2017 which promotes the quality of a democratic and dignified 2018 Election.

Because research is carried out under natural conditions, qualitative research methods can also be called naturalist research methods in which the collected data and analysis are qualitative. So the research conducted is on natural objects, namely objects that develop as they are without being influenced by researchers including the dynamics of the object. In a qualitative research the researcher is the instrument, (Human Instrument). In order to obtain or obtain a broader and deeper understanding of the social situation to be examined in this case the implementation of PKPU's policy No. 2 of 2017.

Qualitative methods are also used to get in-depth data, a fact that contains meaning. The meaning is actual data, definite data and is a value behind the visible data. Therefore, qualitative research is not emphasized that the results of the research must be generalized, but rather emphasize or prioritize the meaning [9], [10].

In this study, more data analysis techniques were carried out together with data collection. The data analysis technique conducted in this study is according to [10]: First, Data Reduction. The data obtained is recorded in the form of detailed descriptions which are then reduced to be selected only according to the focus of the problem under study. In conducting data reduction, it was carried out from the beginning to the end of the study. Second. Data Presentation. After being reduced, the data resulting from the reduction is presented to make it easier to understand what is happening, then plan the next work based on what is understood. Third, Data Verification. Verification is done from the beginning of the research until the research ends. It should be emphasized that based on the analysis of relevant data, the conclusions expressed at first (ongoing research) are still temporary and will change if there are no strong supporting evidence at the next data collection stage.

In carrying out qualitative data analysis, according to [10], it can be done interactively and can last continuously until complete or the data is completely saturated. As for what is done in data analysis, among others: Data reduction, data presentation and conclusion or data verification.

\section{RESULTS AND DISCUSSION}

Specifically, PKPU Number 2 of 2017 regulates several things about voters in the 2018 post-conflict local election, among others those regulated are: about population data provided by the Ministry of Home Affairs and if the Minahasa is issued by the Regent. Furthermore, it regulates the Temporary Voter List, Provisional Voters List of Improved Results, Permanent Voters List, Additional Voters List. Including also regulating Additional Special Voters or DPKtb where are voters who have a residence identity but have not been registered in DPT and DPTb. This is expected to help every Indonesian citizen, especially the people in Minahasa Regency, to be able to exercise their political rights.

The duties and responsibilities of Minahasa KPUD on policies related to KPU Regulation No. 2 of 2017 in updating data are very crucial in the process of running this PKPU implementation. The forms of implementation include implementing technical guidance on updating and disseminating data on Voters to PPK, then forming TPS by allocating Voters to a maximum of 500 (five hundred) voters in (Model A.0-KPU form) taking into account geographical conditions and regional administration; then copying village/urban 
community voter data (Model A.0-KPU form) and TPS-based voter data (Model A.0-KPU form) into the flash drive to be submitted to the PPK; then print and sign the Model A.0-KPU form before submitting it to PPS; is processed by printing and duplicating Voter Data Update forms; and submit the printout of TPS-based Voters data (Model A.0-KPU form) to PPK for submission to PPS; thus further up to the submission of TPS-based voter data to PPS.

The Minahasa KPUD also strives that any political rights of the community can be used in the election. However, these efforts must be based on applicable rules. The KPUD applies additional voter lists if someone has registered in the DPT at a polling station which due to certain circumstances the Voters cannot use their right to vote at the polling station where they are registered. Specific circumstances are if a person cannot choose his place of residence at the time of the election not because of his own will or circumstances which are completely unexpected by the voter, for example due to illness, being a prisoner, natural disaster, so that he cannot exercise his right to vote at the polling station where he is registered. However, additional voter data must be available before 3 days of voting, this is in accordance with Article 25 paragraph 3 of PKPU Number 2 of 2017. So to be accommodated into additional voter lists in accordance with article 25 paragraph (1) as referred to in Article 25 paragraph (2), voters must show proof of valid identity and proof that they have been registered as voters in the DPT at the original polling station.

The presence of PKPU Number 2 of 2017 is the power of the election organizers in this case the KPU, to accommodate the killing of the political rights of the public in the conduct of elections. However, the implementation is strongly influenced by various factors, including:

\section{A. Communication}

In general, communication factors become factor that influence the implementation of PKPU's policy No. 2 of 2017 by Minahasa KPUD which is in the form of information that is not clear to the public. For example, what happens is that most people do not know clearly about the existence of rules regarding the Addition Voters List (DPPh) and the mechanism according to PKPU Number 2 of 2017 article 25. Article 25 is indeed intended to accommodate those who move addresses or are not in place at the time of day breakthroughs but must be based on applicable mechanisms. This is often not understood by the public. The cause of this error is the limited communication as well as the clarity that is simplistic so that the community becomes misunderstood. Communication is one of the factors that influence the implementation of PKPU No. 2 of 2017. Edward III in [11], stated that communication is a process of distributing information from policy makers to the implementers so that they know what to do. In order for communication to be effective, the right people must be chosen to convey and receive information so that the information is accurate.

\section{B. Resources}

The most important support in the implementation of this policy is the availability of adequate resources in the Minahasa KPUD as election organizers. One of the problems is human resources that have the ability to process the modified voter list data. This has become very serious in an effort to compile an accurate and credible voter list. Especially when conducting information about PKPU's policy No. 2 of 2017 Article 25 is the least number of personnel possessed. Moreover, the Minahasa KPUD has been plotted in their respective duties. Consequently, the socialization and training affairs that are ideally made in each PPS are difficult to implement.

Another very important thing is the source of funds. Limited resources to support large and diffuse voter data collection. Based on these things, it can be emphasized that resources greatly affect the implementation of PKPU's policy No. 2 of 2017. Inadequate human resources, funding resources and infrastructure means that this implementation is not optimal. As a result, people feel that their desires are not fulfilled in accordance with the purpose of the policy, which is to accommodate all Indonesian citizens, especially in Minahasa, to get their rights as citizens in politics through general elections.

According to Edward III in [11], resources are important in the implementation of good policies. The indicators used to see the extent to which resources affect policy implementation in this case are the implementation of PKPU Number 2017 by the Minahasa KPUD consisting of: Staff. The most important resource in policy implementation is staff or employees (street-level bureaucrats) who have not been maximally empowered. Information. In the implementation of PKPU Number 2017, information is also an important aspect. The information in question is: first, information relating to how to 
implement the PKPU policy in this case is a technical activity derived from the formulator of this policy and more disseminated to the Minahasa KPUD to decide on technical activities that must be carried out. Secondly, information regarding compliance data from the implementers on the rules and regulations that have been established, this is not done because there are no such provisions. Authority. In general, authority must be formal so that orders can be carried out effectively, which in this case the Minahasa KPUD in exercising authority is more focused on an informal approach so that it cannot carry out its tasks to the fullest extent of its authority. Amenities. Lack of physical facilities (facilities) becomes a problem in PKPU's implementation number 2 of 2017 by Minahasa KPUD Physical facilities are an important factor in policy implementation. Although the implementer has competent staff, the amount is sufficient and capable, but if there are no supporting facilities (facilities and infrastructure), the implementation of the policy will not succeed.

\section{Characteristics of Implementing Agents}

In the organizational structure in the Minahasa KPUD based on Law No. 15 of 2011 there are two structures, namely the commissioners and secretariat staff. In this case the commissioners are assisted by the secretariat staff in carrying out their respective duties. But sometimes becomes a problem is the occurrence of misunderstandings that result in overlapping authority and tasks that often hinder work. The patterns of relationships that occur in the Minahasa KPUD are organizational relationships based on their respective responsibilities. However, because the portion of the work is different between the commissioners and the secretary, sometimes the relationship is not strong. According to Metter and Horn [10], the characteristics of implementing agents include bureaucratic structures, norms and patterns of relationships that occur in the bureaucracy, all of which will affect the implementation of a policy. From these data, it is confirmed that the characteristics of different implementers in the Minahasa KPUD, namely the commissioners and the secretariat, will influence the implementation.

\section{Relations between Organizations}

In implementing PKPU's policy number 2 of 2017 the Minahasa KPUD is also assisted by other relevant parties. For example, about population data by synchronizing with data from the government in this case the Minahasa Regency Population and Civil Registration Service. Likewise related to the regulation regarding the determination of the DPT, the Minahasa KPUD must also cooperate with the Minahasa Panwaslu (Election Supervisory Committee), in other words that the success of voter data collection is also supported by other related institutions. To get the most out of a program to be implemented, the implementation of a program needs support and coordination with other agencies. Therefore, coordination and cooperation is needed with other agencies so that the policy/program objectives are achieved; (Meter and Horn: in [10]. Thus it can be stated that the relationship between organizations greatly influences the implementation of this PKPU policy by the Minahasa KPUD when to conduct data collection and updating voter data for the 2018 Election in Minahasa District.

\section{E. Implementor attitude}

As the organizer of the general election in implementing PKPU No. 2 of 2017, Minahasa KPUD in this case the Commissioners and secretariat staff are less committed to maintaining good attitudes and positive relations that can attract the sympathy of stakeholders, especially political party leaders and candidates for Pemilukada (Regional Heads Election), towards the settlement of every problem related to voter data collection and updating, including the problem of additional voters included in the final voter list. Because sometimes decisions taken for example DPT questions often get bad responses from political parties, this can be seen when it is felt that what was decided by the Minahasa KPUD did not accommodate the interests of stakeholders. Edward III said [14], the disposition or various tendencies become one of the factors that have important consequences so that the implementation of the policy extends effectively. If each implementer has a positive tendency or attitude or there is support for policy implementation, there is a high probability that policy implementation will be implemented in accordance with the initial decision. Likewise, the opposite will occur, if the implementers are negative or refuse to implement policies due to conflicts of interest, the implementation of the policy will face serious obstacles.

\section{CONCLUSIONS}

PKPU Number 2 of 2017 Specifically regulating several matters concerning voters in the Pemilukada (Regional Heads Election), among others, is regulated as follows: concerning population data or D4 provided by the Ministry of Home Affairs and if 
Minahasa is issued by the Regent of Minahasa. 2) The duties and responsibilities of the Minahasa KPUD against policies related to KPU Regulation No. 2 of 2017 in preparation for updating the data are very decisive in the process of running this PKPU implementation. 3) Minahasa KPUD seeks to ensure that every political right of the community can be used in the regional heads election (regent). 4). The Minahasa KPUD applies additional voter lists if someone has registered in the DPT at a polling station which due to certain circumstances the Voters cannot use their right to vote at the polling station where they are registered. 5). PKPU Implementation Number 2 of 2017 is strongly influenced by various factors, namely: a). Communication Factors. b). Resource Factors. c). Characteristics of Implementing Agents, d) Relationships between organizations, and e). Implementor attitude.

\section{REFERENCES}

[1] Nurhayati, "Pendataan Pemilih Pilkada dan Segala Permasalahannya," Kompas, Jakarta, 2018.

[2] S. P. Huntington, "The clash of civilizations?," Foreign Aff., pp. 22-49, 1993.

[3] R. Istania, "Split Ticket Voting: Menumbuhkan Kegairahan Politik Lokal?," J. Borneo Adm., vol. 5, no. $1,2009$.

[4] A. Jimly, "Pengantar Ilmu Hukum Tata Negara," Jilid I Cetakan I, Sekr. Jenderal Mahkamah Konstitusi, 2006.

[5] B. Winarno, Kebijakan Publik: Teori dan Proses, Revsion. Yogyakarta.: Media pressindo, 2007.

[6] N. Riant, "Public policy," Elex Media Komputindo, Jakarta, 2014.

[7] A. Gaffar, Politik Indonesia: transisi menuju demokrasi. Pustaka Pelajar, 1999.

[8] S. Abdul wahab, Pengantar Analisis kebijakan publik. Malang.: UMM Press, Malang., 2008.

[9] L. J. Moleong, Qualitative Research Methodology, Revised. Jakarta: PT. Remaja Rosdakarya Offset, 2014.

[10] M. B. Miles and A. M. Huberman, "Analisis data kualitatif." Jakarta: UI press, 1992.

[11] A. G. Subarsono, Analisis kebijakan publik: konsep, teori dan aplikasi. Pustaka Pelajar, 2005. 